\title{
Mirosław Jankowiak
}

Instytut Slawistyki PAN

Warszawa

\section{Lukasz Grajewski}

Studium Europy Wschodniej UW

Warszawa

\section{SZLAKIEM BIAŁORUSKICH POLESZUKÓW (RAPORT Z BADAŃ TERENOWYCH)}

\section{Informacje wstępne}

Niniejszy raport powstał na podstawie badań terenowych przeprowadzonych w drugiej połowie sierpnia $2010 \mathrm{roku}^{1}$. W trakcie dwutygodniowej ekspedycji przebadaliśmy 13 miejscowości. Był to Pińsk i 11 wsi rejonu pińskiego: Stajki (Стайкі), Mała Wólka (Малая Вулька), Wielka Wólka (Вялікая Вулька), Żytnowicze (Жытновічы), Wielkie Dzikowicze (Вялікія Дзіковічы), Miestkowicze (Месткавічы), Wujwicze (Вуйвічы), Boryczewicze (Барычэвічы), Biżerowicze (Біжэравічы), Miesiatycze (Месятычы) i Szołomicze (Шаломічы). Przeprowadziliśmy również badania w jednej wiosce rejonu stolińskiego - Wikarowiczach Małych (Малыя Вікаровічы). Łącznie przeprowadziliśmy 21 wywiadów z 26 osobami.

Ze względu na dialektologiczny charakter ekspedycji do badań zostały wybrane niezbyt duże wsie, oddalone od centrów. Rozmowy odbyliśmy przede wszystkim z osobami starszymi, u których lokalna gwara poleska mogła się najlepiej zachować, i z tymi, którzy od urodzenia mieszkają $\mathrm{w}$ danej miejscowości bądź przemieszczali się tylko w obrębie rejonu. Wielu z nich zakończyło edukację na kilku klasach.

${ }^{1}$ Badania terenowe zostały przeprowadzone przez dr. Mirosława Jankowiaka z Instytutu Slawistyki PAN i mgr. Łukasza Grajewskiego, absolwenta Studium Europy Wschodniej UW. W czasie ekspedycji służył pomocą również Roman Burenko, pińczanin. Ekspedycja odbyła się w ramach grantu „Dialektologia białoruska” afiliowanego przy Instytucie Slawistyki PAN, a realizowanego przez prof. Ninę Barszczewską i dr. Mirosława Jankowiaka. 


\section{Obwód brzeski}

\section{Rejon piński}

miejscowości objęte badaniami

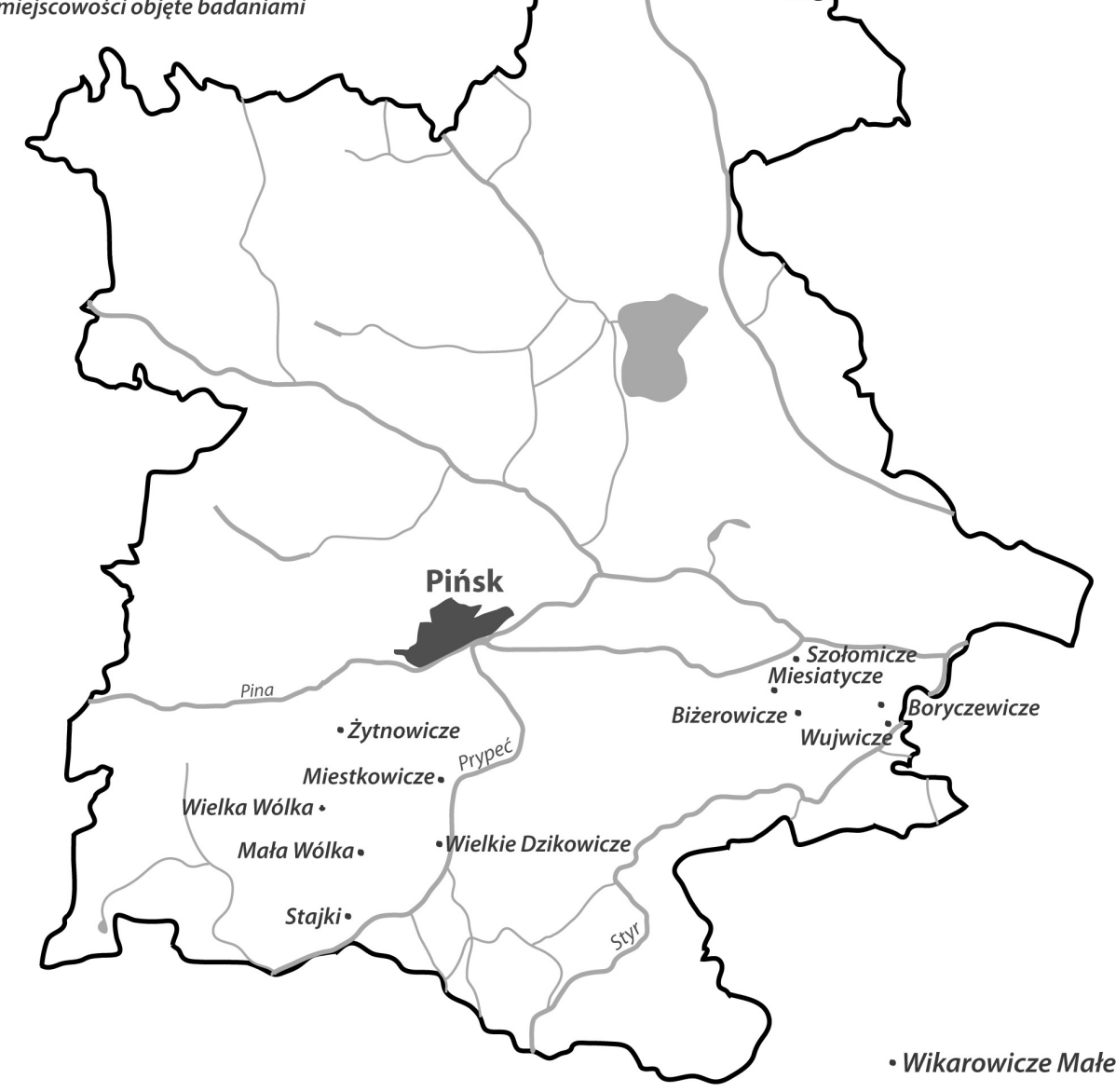

oprac. Marlena Nowak

Ponad połowa spośród rozmówców to osoby urodzone przed II wojną światową, co dawało możliwość uzyskania od nich informacji o tzw. polskich czasach, pamiętają bowiem jeszcze okres międzywojenny.

W trakcie rozmów poruszaliśmy następujące tematy: sytuacja językowa we wsi (język w różnych sferach życia, różnice pomiędzy gwarą okolicznych wsi), kwestie tożsamości narodowej, wyobrażenia mieszkańców o Polesiu i Poleszukach, tradycje i zwyczaje (poczynając od kultury uprawy roli, architektury, przez tkanie, wyszywanie, wypiekanie chleba, a kończąc na obrzędach weselnych czy pogrzebowych i praktykach znachorskich), kwestie wyznania czy też stosunek do procesu osuszania bagien poleskich. 
Ważnym aspektem naszych rozmów były sprawy związane z okresem międzywojennym - polskimi posiadaczami ziemskimi czy też wątek wsi chłopskich, zwanych tutaj mużyckimi, i szlacheckich. Celem niniejszego raportu jest zatem krótkie omówienie powyższych zagadnień, głównie na podstawie wypowiedzi naszych rozmówców.

W badaniach zastosowano metodę biograficzną, szeroko wykorzystywaną przez etnografów i socjologów ${ }^{2}$, a polegającą na przeprowadzaniu wywiadów swobodnych, lekko tylko sterowanych przez badacza. Rozmowa, wspomagana kwestionariuszem pytań, trwała zazwyczaj około półtorej godziny, co wystarczało, aby poruszyć odpowiednią liczbę tematów niezbędnych do zrozumienia sytuacji językowej i historyczno-społecznej danej wsi, a jednocześnie dawało możliwość przeanalizowania obecnego stanu gwary bez wykorzystania tradycyjnego kwestionariusza dialektologicznego.

Zachodnie Polesie, choć bardzo dobrze przebadane przez przedstawicieli różnych dyscyplin naukowych, zarówno z Białorusi oraz Polski, jak i z innych krajów, ciągle należy do najchętniej odwiedzanych obszarów tej części Europy. Niewątpliwie jednym z najważniejszych tego powodów jest jego archaiczność - zachowanie, pomimo postępujących zmian cywilizacyjnych, gwary poleskiej, tylko w niewielkim stopniu zrusyfikowanej, lokalnej architektury czy też zwyczajów. Wyliczenie w niniejszej pracy wszystkich nazwisk osób interesujących się powyższą tematyką jest niemożliwe, dlatego ograniczymy się do kilku wybranych. Zagadnieniem gwar poleskich zajmowali się i nadal zajmują współcześni dialektolodzy białoruscy: Fiodor Klimczuk [Клімчук 1983], Jurij Czarniakiewicz [Чарнякевіч 2009] i śp. Wiaczesław Werenicz [Вярэніч 2009]. Regionowi temu poświęcono też słowniki [Дыялектны слоўнік 1989] i atlasy dialektologiczne [Лексіка 2008].

W Polsce już w okresie międzywojennym Polesie, oczywiście jego część znajdująca się w granicach II Rzeczypospolitej, stało się obszarem wielu ekspedycji naukowych, głównie etnografów - Józefa Obrębskiego ${ }^{3}$ i Kazimierza Moszyńskiego - czy też filologów, np. Józefa Tarnackiego [Tarnacki 1936]. Obecnie obszar ten jest badany m.in. przez etnograf Annę Engelking. Polesiu poświęcono w Polsce również przewodniki turystyczne [Marczak 1935; Rąkowski 2001].

\section{Charakterystyka badanego obszaru}

Rejon piński, wchodzący w skład obwodu brzeskiego, obejmuje obszar 3261 $\mathrm{km}^{2}$ i należy do największych spośród znajdujących się w granicach Białorusi. Zamieszkuje go obecnie 52 tys. osób, z czego Białorusini stanowią 92\%, Rosjanie 2,6\%,

\footnotetext{
${ }^{2}$ Zob. np. [Kłoskowska 1996] czy [Kabzińska 1999].

3 Zob. ostatnio wydane prace Józefa Obrębskiego: [Obrębski 2007] i [Obrębski 2005].
} 
Ukraińcy 2,6\%, Polacy $1,6 \%$ oraz inne narodowości - niecały $1 \%{ }^{4}$. Zdecydowana większość to osoby wyznania prawosławnego. W Pińsku, gdzie mieszka wielu katolików (katolicyzm jest najaktywniejszym i najszybciej rozwijającym się tutaj wyznaniem), funkcjonuje kilka kościołów. W pozostałych badanych miejscowościach nie ma ani świątyń katolickich, ani katolików ${ }^{5}$.

Rejon piński przecina wiele rzek (Prypeć, Styr, Jasiełda, Pina) i kanałów, a liczne bagna (stanowiące tutaj obecnie 13,6\%) oraz lasy (32\% całego rejonu) znacznie ograniczają transport i kontakt mieszkańców odleglejszych wsi. Sprzyja to lepszemu zachowaniu tradycyjnej kultury niż w innych regionach Białorusi. Wszystkie badane miejscowości znalazły się w obszarze położonym na południe od Pińska i ograniczonym od północy rzeką Piną i Jasiełdą, od wschodu rzeką Styr, od południa lasami i granicą ukraińską, a od zachodu lasami rozciągającymi się od granicy ukraińskiej na północ po linię Newel-Wielka Wólka-Żytnowicze-Domaszyce. Obszar ten, w przeciwieństwie do położonego na północ od Pińska, charakteryzuje ukraiński charakter gwar i poleski typ kultury.

W czasach średniowiecznych Polesie zamieszkiwali Dregowicze. W X wieku stało się częścią Rusi Kijowskiej. W okresie rozbicia dzielnicowego, aż do połowy XII wieku, rejon piński znajdował się w granicach księstwa turowsko-pińskiego. W 1341 roku, po podbojach książąt litewskich, znalazło się w Wielkim Księstwie Litewskim. Jeszcze przed unią lubelską 1569 roku Pińsk był najpierw stolicą starostwa (1539), a następnie został włączony do województwa brzeskiego (1565-1566). Po rozbiorach Rzeczypospolitej Pińszczyzna była częścią imperium rosyjskiego. W okresie tym zniesiono na przykład postanowienia unii brzeskiej (1839), co osłabiło wpływy Rzymu, a wzmocniło prawosławie. Po traktacie ryskim w 1921 roku Polesie, jak wszystkie ziemie białoruskie, zostało podzielone: zachodnie weszło w skład II Rzeczypospolitej; wtedy też było najbiedniejszym regionem całego kraju. Zakończenie II wojny światowej przyniosło ponowne zmiany granic. Rejon piński stał się częścią Białoruskiej SRR, aż do 1991 roku, kiedy Białoruś odzyskała niepodległość.

\section{Wybrane tematy}

W zebranych przez nas wywiadach można wyodrębnić kilka ważniejszych tematów, które powtarzały się prawie u wszystkich informatorów. Poniżej omawiany te $\mathrm{z}$ nich, które są, naszym zdaniem, warte uwagi.

\footnotetext{
${ }^{4}$ Statystyka została zaczerpnięta z publikacji Powszechny spis ludności Republiki Białoruś na 2009 rok.

${ }^{5}$ W niektórych wioskach mieszka niekiedy jedna czy dwie osoby tego wyznania.
} 


\section{Wyobrażenie o Polesiu i Poleszukach}

Zachodnie Polesie, wchodzące w skład Białorusi, które nas najbardziej interesuje $\mathrm{w}$ niniejszym raporcie, traktowane jest obecnie jako region historyczno-etnograficzny i pokrywa się mniej więcej z zasięgiem zachodnich gwar poleskich. Zachodnie rubieże wyznacza granica administracyjna z Polską, na wschodzie dorzecze rzek Horynia i Stwigi, gdzie rozpoczyna się wschodnie Polesie. Północną granicę stanowi zasięg występowania etnonimów, którymi mieszkańcy swoich południowych sąsiadów określają Poleszukami, a północnych Lićwinami [Народная 2002: 159, 160], południową natomiast - granica administracyjna $\mathrm{z}$ Ukrainą.

Z kolei granice Polesia w Słowniku geograficznym Królestwa Polskiego i innych krajów stowiańskich zostały przedstawione jako „[...] szeroki pas kraju pokryty lasami (stąd nazwa), ciągnący się po obu brzegach rzeki Prypeci między Bugiem a Dnieprem. Obejmuje on znaczniejszą część gub. mińskiej, mianowicie powiaty: piński, mozyrski, bobrujski oraz część słuckiego i ihumeńskiego, dalej z gub. grodzieńskiej znaczną część powiatów: kobryńskiego, prużańskiego i słonimskiego, z gub. wołyńskiej część powiatu rowieńskiego, włodzimierskiego, nowogród-wołyńskiego (zwiahelskiego), owruckiego, z gub. kijowskiej pow. radomyski i wreszcie z gub. homelskiej część pow. rohaczewskiego, homelskiego i bychowskiego. Ścisłe oznaczenie granic Polesia jest bardzo trudne i tylko w przybliżeniu można powiedzieć, że tworzy ono trójkąt, wierzchołki którego stanowią miasta: Brześć Litewski, Mohylew nad Dnieprem i Kijów [Słownik 1884: 579, 580].

Tak natomiast obszar Polesia wyznaczył Józef Obrębski: „Granice kraju Poleszuków [...] obejmują fizjograficzny kształt kotliny poleskiej w jej maksymalnym zasięgu, ograniczonym od południa Wyżyną Wołyńską, od północy zaś - Nowogródzką [...]. W ten sposób obszar Polesia będziemy mogli ująć z grubsza w schemat. Południową jego granicę przeciągniemy linią wyznaczoną przez następujące punkty: jezioro Świtaź, Kowel, Klewań, Aleksandria, Korzec. Za północną granicę przyjmiemy linię szosy brzesko-słuckiej [...]. Jeśli wkroczymy na ten obszar i spróbujemy odnaleźć na nim Poleszuków, nie będzie to rzeczą łatwą. Więcej nawet, dla bardzo szerokiego pasa na Polesiu okaże się to wręcz niemożliwe. I to nie tylko dlatego, że rzeczywistość przeczy znanemu nam już wizerunkowi Poleszuka u jego sąsiadów, ale przede wszystkim dlatego, że ludność bardzo rozległych - zwłaszcza na południu - stref Polesia zupełnie nie poczuwa się do poleskości [...]” [Obrębski 2007: 199, 200].

Józef Obrębski wyznaczył granicę Polesia, kierując się między innymi wypowiedziami ludności nieuważającej się za Poleszuków, ale wskazujących na swych sąsiadów właśnie jako na osoby o takim rodowodzie. Uwaga polskiego etnografa, zacytowana powyżej, jest aktualna i dzisiaj. Nawet na tak niewielkim obszarze jak badany przez nas rejon piński po przeprowadzeniu niewielu wywiadów dało się zauważyć, że sami Poleszucy (osoby uważające się za Poleszuków) nie są w stanie jednoznacznie określić granic Polesia. Spytani o Polesie, zazwyczaj wskazywali na wsie położone bardziej na południe i południowy wschód, ukonkretniając, że 
prawdziwe Polesie znajduje się tam, „gdzie są prawdziwe poleskie lasy i bagna i że tu już nie ma prawdziwego Polesia”. W ich mniemaniu znajduje się ono zatem bliżej Stolina czy granicy z Ukrainą, a wsie położone w odległości do $10 \mathrm{~km}$ na południe od Pińska nie zaliczają się jeszcze do Polesia.

Można również zauważyć, że obszar zamieszkiwany przez osoby, które obecnie uważają się za Poleszuków, pokrywa się, przynajmniej w rejonie pińskim, z granicą etniczną Polesia wyznaczoną niegdyś przez Obrębskiego. W miejscowości Stajki, Małej Wólce czy Wielkiej Wólce ich mieszkańcy mówili o sobie jako o Poleszukach, a w Żytnowiczach, położonych już nieco na północ, raptem $6 \mathrm{~km}$ bliżej Pińska, rozmówcy zaznaczali, że tu już nie ma Polesia. Obszar położony powyżej wymienionych miejscowości określony został przez Obrębskiego za peryferyczny obszar Polesia etnicznego, gdzie widoczne jest ciążenie etniczne ku grupom pozapoleskim.

Tak na pytanie, gdzie znajduje się Polesie, odpowiadali nasi rozmówcy:

[A dzie Palessie?] Nie u nas, to, musi, tut, za Stolyn, u tu storonu. Polieszuky to zwały [ich], alie nie naszych, to tam [Nadzieja Sidorczuk, ur. 1935, Wujwicze].

Osoby nieco bardziej oczytane tak określały terytorialny zasięg swej krainy:

A hranica Poliesja, to bresckaja obtaść, pa mojmu pa Baranawiczy i do Homielia buła polieskaja obłaść, heta Turau, Mozyr, i czassć ukraińskoj terytorii [Iwan Michalczuk, ur. 1928, Mała Wólka].

Mieszkańcy rejonu pińskiego, choć za Polesie uznawali inny niż zamieszkały przez nich region, zaznaczali jednak, że pomiędzy ludźmi z ich wiosek a żyjącymi w rejonie stolińskim nie ma widocznych różnic w wyglądzie czy zwyczajach:

Stolinski rajon eto Polissie, tut nie. To stolinski rajon, to tam Polissie. Tam [ludzie] takije samyje jak i my [Zosia Boryczewska, ur. 1935, Wujwicze].

$\mathrm{Na}$ uwagę zasługuje również porównanie dawniejszego, chociażby z okresu międzywojennego, wizerunku Poleszuka z tym, który pozostał w pamięci naszych rozmówców, i co możemy zobaczyć współcześnie, przemierzając wsie. Tak opisywał niegdyś jego typowy wygląd Józef Obrębski: „[...] rosły, wysoki, barczysty ${ }^{7}$, silny dziadźko, z długą brodą i ściętymi na karku włosami, w koszuli lub rubaszce wyrzuconej na płócienne spodnie, opasany czerwoną krajką lub [...] branym czerwonym pasem wełnianym, obuty «niepremienno» w łapcie łykowe lub łozowe [...] jeszcze kaleta, tzn. torba skórzana lub pleciona $\mathrm{z}$ łyka, przerzucona przez ramię i zawierająca zapasy chleba, pieniądze itp." [Obrębski 2007: 262].

${ }^{6}$ Wzrost i tężyzna były różnie postrzegane - w zależności od miejsca zamieszkania - Poleszucy zamieszkujący lasy i tereny bagienne byli określani raczej jako niscy.

${ }^{7}$ Wypowiedzi rozmówców przytaczane są w zapisie półortograficznym. Pytania zadawane były po białorusku bądź w mowie zbliżonej do gwary poleskiej. 
Z powyższego wizerunku nie ostało się praktycznie nic - współcześni Poleszucy są zazwyczaj ubrani tak samo jak mieszkańcy pozostałych regionów Białorusi, tylko okazjonalnie, zazwyczaj na święta, wkładają lokalny strój ludowy. Charakterystyka Poleszuka, przedstawiana nam przez naszych rozmówców, nie odbiega jednak wiele od sporządzonej kilkadziesiąt lat temu przez Obrębskiego. Na pytanie, czym wyróżnia się Poleszuk, praktycznie zawsze uzyskiwaliśmy jednakową odpowiedź że Poleszuk mieszka na Polesiu, nosi słomianą czapkę i łapcie, zamieszkuje tereny zalesione i bagniste:

Tut Poliesje to i Polieszuki. Polieszuk kołyś buu u lapciach, u joho swoje raboty buło tam tkanje, kapiel'usz taki z sołomy i takej buu Polieszuk, Polieszuk to u łapciach usio uremja [Iwan Michalczuk, ur. 1928, Mała Wólka].

Jednym z ciekawszych zagadnień jest niewątpliwie określenie, czy też skategoryzowanie pojęcia Poleszuk. Czy wskazuje ono na etniczność bądź naród? Z naszych rozmów wynikało, że chyba nie. Józef Obrębski pisze raczej o cesze, którą nazwał anachronizmem kulturowym. Pewien zbiór cech związanych z ubiorem lub tradycjami był rozpowszechniony wcześniej na większym terytorium, obecnie zaś (czyli w czasach Obrębskiego) cechy te pozostały tylko w regionie, gdzie "cywilizacja” jeszcze nie dotarła, czyli na obszarze odciętym bardziej od tejże cywilizacji, dzięki czemu zachowały się stare cechy. Biorąc pod uwagę wypowiedzi mieszkańców, można odnieść wrażenie, że w rejonie pińskim na pojęcie poleszuckość bardzo mocno nałożyły się inne kategorie: białoruskość i ukraińskość, mocniejsze jest też przywiązanie, głównie administracyjne, do jednego czy drugiego państwa. Można być jednocześnie i Białorusinem, i Poleszukiem - takie paralelne poczucie tożsamości nie było sporadyczne. Niewątpliwie dużą rolę odegrała też władza sowiecka, a wspomaga obecne kierownictwo niepodległej Białorusi, jak również zmiany społeczno-ekonomiczne. Tak na pytanie o narodowość i tożsamość odpowiadali nasi rozmówcy:

- A jakoj nacyi tut żywuć liudzi?

- Biłorusy u asnaunom u nas, Biłorusy.

- A Palieszuki tut żywyć?

- Da, my że i jeść Polieszuki.

- A jakaja roźnica pamiż Palieszukami a Biełarusami?

- A to to samaje, biełaruskija Polieszuki my, Poliesje, tamu szczo na Poliesji żywuć.

[Maria Kazak, ur. 1937, Stajki].

Niewątpliwie jedną z widocznych obecnie cech poleszuckich jest przywiązanie do wody - licznych tutaj rzek, strumieni i wszelkiego typu akwenów wodnych. Do dzisiaj można spotkać poleszuckie łodzie, nazywane coraz rzadziej z dawna „czajkami”, „czubarkami” czy „podjazdkami”, a coraz częściej współcześnie - z białoruska czy rosyjska - „łodkami”. To właśnie dzięki rybołówstwu region uzyskał duże 
znaczenie $\mathrm{w}$ gospodarce kraju. $\mathrm{W}$ okresie międzywojennym połów ryb przynosił nie tylko handlarzom, ale i chłopom spore dochody, a towar wożono i sprzedawano do tak odległych miejscowości, jak Wilno, Kijów czy Warszawa. To poleskie „Złoto” niejednokrotnie pomagało miejscowej ludności uniknąć głodu, jak chociażby tuż po zakończeniu II wojny światowej, kiedy brakowało żywności [Памяนฺb 1998: 216]. Tak zaawansowanym handlem „płodów wodnych” zajmowała się jednak przede wszystkim ludność żydowska, która w okresie międzywojennym stanowiła w Pińsku około 90\% mieszkańców. Poleszucy gorsze ryby zatrzymywali dla siebie (suszyli lub dodawali do potraw), a lepsze gatunki sprzedawali kupcom, którzy na łodziach podpływali bliżej wiosek położonych wzdłuż Prypeci, Horynia czy Styru [Ossendowski 2010: 104].

\section{Szlachta i mużyki}

Tematem, który bardzo często pojawiał się w naszych rozmowach, był podział miejscowości na szlacheckie i tzw. mużyckie, czyli chłopskie. Rozmówcy bardzo dokładnie określali, jaki charakter ma każda z nich. Wskazywali również, którzy z mieszkańców mają korzenie szlacheckie, a którzy chłopskie. Jako definitywnie szlacheckie określono następujące miejscowości: Stajki, Szołomicze, Kaławrowicze czy Dzikowicze Wielkie, jako chłopskie natomiast Małą i Wielką Wólkę. Były również wsie mieszane, np. Boryczewicze czy Wujwicze ${ }^{8}$ :

Szliachta to buły u Stajkach, tam. A u nas nie buło, nie u Małych [Wólce] nie u Bol'szych, ni u Żytnowiczach. Za to szliachta u Dzikowiczach buła Bol'szych, tam buła [Nadzieja Chodźko, ur. 1942, Wólka Wielka];

A u nas pomiszany, primerno nas szczytaj, my mużyky, a ta baba, uo, kazali szliachcianka $i$ u hetoj chaty szliachcianka, a u hetoj toże mużyky. Pomiszany [my] tut woobszczem [Nadzieja Sidorczuk, ur. 1935, Wujwicze];

Toż my sama szliachta, $u$ nas buły dwie-try chaty mużykou, a tak u nas wosiemdziesiat procentou to Dzikawickich, tam dwie, try siemji Kozliakouskije i Poluchowiczy, każetsja, a Ihnatowiczy to uże mużyki buły [Michał Dzikowicki, ur. 1926, Dzikowicze Wielkie].

Kilkadziesiąt lat temu istniały jeszcze spore różnice pomiędzy stanami społecznymi, o czym świadczą nie tylko badania polskich etnografów, między innymi Józefa Obrębskiego, ale nawet wzmianki w przewodniku turystycznym po Polesiu z 1935 roku, którego autor pisał: „U szlachty zaściankowej, nawet uboższej, chata przeważnie z ganeczkiem - jest zazwyczaj większa niż u «mużyków» czyli chłopów.

${ }^{8}$ Jak czytamy w Archiwum poleskim W. Werenicza, wioskę Boryczewicze rozdzielała ulica - po jednej stronie mieszkała szlachta, po drugiej chłopi, z kolei we wsi Wujwicze chłopi zamieszkiwali zachodnią część miejscowości (za cerkwią), a szlachta wschodnią [Вярэніч 2009: 26,34]. 
[...] Uboga szlachta zaściankowa stara się w miarę możności odróżnić wierzchnim strojem od gminu. Zwykle nosi buty, a tylko do niektórych zajęć używa łapci, głowę nakrywa w lecie kaszkietem, na grzbiet narzuca fabryczny surdut" [Marczak 1935: 29, 36].

Badania wykazały, że obecnie między drobną szlachtą a mużykami nie ma znaczących różnic - ani w gwarze, którą posługują się obydwie grupy społeczne, ani w zamożności, zwyczajach, architekturze domostw czy nawet wyznaniu (wszyscy są prawosławni). Również ubranie jest jednakowe, co wynika nie tyle z przyswojenia przez szlachtę zwyczajów chłopskich, ile z postępującej sowietyzacji, a następnie $\mathrm{z}$ coraz większej łatwości zdobycia w miarę tanich fabrycznych ubrań.

Brak poważniejszych różnic między tymi dwiema grupami społecznymi potwierdzają liczne wypowiedzi naszych rozmówców:

Wony [szlachta też] prawasłauny. Mowa taka sama, tak wony każuć jak i my [Nadzieja Sidorczuk, ur. 1935, Wujwicze];

U mowie to wony [i my] odinakowo howoryty, nie rozliczałas od hetych prostych liudej, odinakowo odeża wa usich buła, i usio derżały [bydło] odinakowo, a czym wony rozliczalisia, nie znaju. Nichto mene nie howoryu, szczo szliachta czym-to otliczałasia [Nadzieja Chodźko, ur. 1942, Wólka Wielka].

Z rozmów wynika również, że szlachta nie legitymuje się obecnie dokumentami, które potwierdzałyby ich status społeczny. Cechą definitywnie odróżniającą są nazwiska; zakończone na -ski czy - cki wskazują, według naszych rozmówców, na szlacheckość, a na -uk, -ucz i -un na pochodzenie mużyckie:

A buła szliachta, to familii, kazali na bukwu ' $i$ ', to Miszeuski, to Krasouski, a tak to jaka heta szliachta, miełkaja szliachta [Marija Kazak, ur. 1937, Stajki];

Familji prosto rozdzieliajuć. Wo, u tej baby to uże mużyckaja familia, nu tam Sidorczuk, to mużyckaja, a uże ja szliachieckaja - Baryczeuskaja. Baryczeuskaja, Katłaur, Szołomicki to szczytałosia szliachieckaja familia, na -ki [Zosia Boryczewska, ur. 1922, Wujwicze].

Sporadycznie nasi rozmówcy wskazywali na pewne różnice w sposobie witania się:

Dobry wieczor to szliachta kazała. Szliachta jak ide, to howoryć dzień dobry, a mużyky jak iszli to, he, to zdraście i usio [Nadzieja Sidorczuk, ur. 1935, Wujwicze].

Nasi rozmówcy zwrócili również uwagę na pewną kwestię obyczajową. Poinformowano nas, że we wsi szlacheckiej gość zawsze zostanie nakarmiony i napojony, w mużyckiej natomiast, pomimo serdecznego przyjęcia, pozostanie głodny i spragniony. Zasada ta potwierdziła się w stu procentach w trakcie naszych badań w rejonie pińskim. 


\section{Czasy polskie}

Obecność Polaków na tym obszarze sięga jeszcze czasów królowej Bony Sforzy, która przeprowadziła reformę rolną - pomiarę włóczną. Objęła ona także obszar Polesia. Dzięki staraniom królowej wybudowano pierwszy na Polesiu kanał łączący Pińsk z wsią Stetyczów, rozpoczęto też proces melioracji. Na jej polecenie ściągnięto osadników z przeludnionej Korony. W ciągu kilkudziesięciu lat Polesie stało się prowincją dość dobrze zagospodarowaną i przynoszącą spore dochody z gospodarki wodnej i leśnej, o czym świadczy chociażby fakt, że sam Pińsk w XVI wieku płacił podatek równy wielkością podatkowi odprowadzanemu przez tak bogate miasta, jak Kijów czy Witebsk [Rąkowski 2001: 198].

W pamięci starszych mieszkańców badanych wsi pozostało wiele wspomnień związanych polskością, głównie jednak z okresem międzywojennym i polskimi rządami, rzadziej z powstaniem styczniowym. Czasy te minęły z jednej strony pod znakiem pracy, nierzadko ciężkiej, u panów - Polaków posiadających większe posiadłości ziemskie, z drugiej względnej stabilizacji, ogólnego porządku i ładu oraz bogactwa lasów i rzek. Każdy z naszych rozmówców wspominał swoją pracę u pomieszczyków. Poniżej przytaczamy kilka wypowiedzi:

Buly, pamieszczyki buly pry Pol'szczi, byli bahatyji liudi, katoryji zimli u ich bahato buło, wo, bo ziemlia buła użo sobstwiennaja, a byli i biednyji, a biednyji to paszli uże, to iszli uże u raby hetyji. Wot, ja primierno, ja hoduwausia, bat'ko buu biedno [żył], ditiej mnoho buło, wosiem sztuk, chłopciu buło, a ja samy starszy i ja poszou $z$ wośmi liet paswyty towar [bydło] u bahateriu, u szliachty, osobienno szliachta jak tam nazywałasia. Mużyky i szliachta, mużyki biednawata żyli, a szliachta osobienno bohato żyła i ja że wosim, diewiat' liet towar propaswiu, u Raczyckoho, u pol'skoho liesnika [...] zimu chodyu u szkotu, a litom towar paswiu u liudej [...]. Baćko pachau szliachieckuju, popowuju, diakowuju ziemliu, na tretiak, naszych dwa snop'y, a joho trecij, eto pri Pol'szczy [...]. [Wasilij, ur. 1922, Wujwicze].

Choć mówiono, że praca u panów była ciężka, to jednak zaznaczano wielokrotnie, że kto chciał pracować, ten nie głodował:

Batk'ko bahaty buu, kułak, to hektarou kupyu. Tut niejaki Wieliczko buu, pomieszczyk, od joho zemliu bat'ko kupyu, to i nieskol'ko hiektarou, to pa try czotyry korowy derżaly, to świnej derżaly kil'ko, to ludej, to robyly ot potu do potu, do pana chodyly, to pan że ż płatyu [za robotę]. Rydzeuski u nas buu pan, maszyna buła u pana, jak u detstwie, usie dety padajut, bo jede maszyna, niuchajut, bo pachne, kołys, kołys to buło [Iryna Kołżun, ur. 1926, Żytnowicze].

Nierzadko dochodziło do sprzeczek pomiędzy wsiami chłopskimi a szlachtą:

Tak po familjam, szliachta to byli dworanie, takije znaczne, u seli to uże nazywalisia mużyki, jak u nas, odna chata. I tam Chojno [wieś mużycka], to my draliś, szto to mużyki, a my szliachta [Michał Dzikowicki, ur. 1926, Dzikowicze Wielkie]. 
W przeciwieństwie do drobnej szlachty bogatsi właściciele ziemscy, posiadający nie tylko wiele hektarów ziemi, ale również różnego typu zakłady, na przykład piwowarskie czy gorzelnie, rozmawiali z chłopami po polsku:

U Baryczewiczach [...] buu nastojaszczyj pan, to uże joho syny buli, Janek odnoho zwały. [...] kamandawau zemlioju Janek [A ziamli szmat u jaho było?] A, od czorta buło. U jaho buu isprawliajuszczyj. [A na jakoj mowie pamieszczyk hawaryu?] $\mathrm{Na}$ pol'skoj, na pol'skoj, toż win poliak. Win i naszu mowu ponimau i swoju ponimau [...]. Toże chodyty hroszy zarobyty do toho pana. Tam buu krasiwyj pałac, dom, jak teper każuć, pałac dwuchetażnyj buu, korou tam buło, czornych skul'ki i zawod spirtny buu u toho pana. U jaho buu zawod takej, to na poli stojałe take [budynek]. Potom u sorokowym wyjichau, to win, musi, bojausia. Spirt z bul'by [robił] [Zosia Boryczewska, ur. 1922, Wujwicze].

Obok kościołów katolickich, które najbardziej oddziaływały na mieszkańców Pińska, największy wpływ polonizacyjny miała polska szkoła, gdzie lekcje odbywały się w języku urzędowym. Nauczyciele w większości pochodzili z centralnej Polski, rzadziej z okolicznych wsi. Zazwyczaj w ciągu siedmiu lat dzieci kończyły cztery klasy:

Ja chodyła u pol'skuju szkołu, za Pol'szczy to czotyry [klasy], $z$ naszej diereuni to postupały u instytuty, $i$ to buło tak odin chtopec to, win oficer, win u Warszawu popau, $i$ iszcze djakon u nas buu. A uroki na pol'skom i nemeckom i nemecki prypodowaty. Buła uczyciel'nica u trecim kłasie z Boryczewicz, a to buty i pryjeżdzyje. U nas buła $z$ Poznania, do czotyroch kłasau wuczyła, a potom uczyła $z$ Boryczewicz [Zosia Boryczewska, ur. 1922, Wujwicze];

Stuchaj wnimatiel'no - perwyj hod chodysz u perwyj kłas, wtoroj - hod, u trecij $d w a, u$ czetwertyj try hoda, heto potuczałasia siemilietka, a czotyry kłasa konczysz. Batiuszka kożnu subotu prijiżdzau, uroki prowodyty z mestnych cerkwau. Uczyli nas pol'skije werszy: „Kto ty jesteś, Poliak maty, jaki znak twój, orzeł bialy”. Pry Pol'szczy to tol'ko po-pol'sku, doma to tak, po-swojmu, a u szkoli to tol'ko po-pol'sku, na wycieczku, jak howoryty, jezdzili parachodam u Pinsk, to na pol'skim jenzyku [Michał Dzikowicki, ur. 1926, Dzikowicze Wielkie].

Proces osuszania bagien poleskich

Jednym z tematów pojawiających się naturalnie w trakcie rozmów z mieszkańcami był proces osuszania bagien poleskich. Okres wzmożonych prac przypadł przede wszystkim na czasy sowieckie, kiedy dominowała gospodarka planowa i zakładano wykorzystanie nowo zdobytych terenów pod przyszłe uprawy. Już w 1950 roku pierwszy sekretarz KC KP(b)BN Patoliczew ogłosił rozpoczęcie wieloletniego projektu, który miał na celu osuszanie białoruskich bagien. Tylko w latach siedemdziesiątych osuszono ponad milion hetarów, co doprowadziło do poważnego zachwiania ekosystemu [Szybieka 2002: 381, 404]. W Pińsku został powołany do życia Główny Zarząd ds. Melioracji Ministerstwa Melioracji i Gospodarki Wodnej 
ZSRR. Wkrótce stolica Polesia zasłynęła jako miasto meliorantów. Prace melioracyjne przerwał kryzys wynikły z rozpadu ZSRR, a władze zdały sobie sprawę, że wieloletnia polityka doprowadziła do zubożenia stanu zwierzyny i roślinności w regionie [Rąkowski 2001: 217].

Zdecydowana większość mieszkańców pamiętających okres międzywojenny podkreślała, że „pry Pol'szczy” panował porządek, prowadzono odpowiednią politykę wobec przyrody, z jednej strony za bardzo w nią nie ingerowano, z drugiej zaś dbano na przykład o drożność rzek i strumieni, a także o różnego typu przystanie rzeczne. Rozmówcy niejednokrotnie podkreślali, że przed wojną nigdy nie brakowało zwierzyny leśnej i ryb w rzekach i jeziorach, a ich ilość była wręcz nie do przejedzenia („można było rękoma zbierać”). Proces osuszania bagien, wycinka lasów i irygacja przeprowadzane przez władze radzieckiej Białorusi, w oczach naszych rozmówców, doprowadziły do zachwiania równowagi w przyrodzie i nieodwracalnych zniszczeń, rzeki zostały zapuszczone, pozarastały, ryby przetrzebiono, również w lasach nie ma już tyle grzybów co przed wojną. Potwierdzają to liczne wypowiedzi:

Usiaka ryba buła. Do wojny, pri Pol'szczi to rybakiu buło, to woda rozliwałasia po pasach i ławity, i nie zapreszczały, i kupliały [ryby na targowiskach od nas], $u$ Warszawu otprawłały. A teper, za miliony sztraf [za łowienie]. [...] Zimoj, i linky i karasi i rukamy braty, szczuki, a my dzieciaci biehajem zbirajem ich [...]. Buło ryby, rukami biery, a teper to nima, usio pozarasto [Michał Dzikowicki, ur. 1926, Dzikowicze Wielkie].

Liczne bagna i lasy dawniej uniemożliwiały jednak swobodne przemieszczanie się i kontaktowanie z pobliskimi wioskami. Jak wspominają mieszkańcy Dzikowicz Wielkich czy Wujwiczów, wiosną, w czasie roztopów, do Pińska lub pobliskiej cerkwi trzeba było docierać na łodzi. Łodzią też przedostawano się do Pińska, aby handlować tam własnymi produktami na miejskim targowisku:

Muż osuszwau Polissie, melioracyju robyu. Tut bołoty [były] oj, tut pislie wojny to nie wejdesz, tak było, to stil'ko wody było, til'ko bołoto. To $\dot{z}$ dorohy byli takije, wel'mo hruzko było, dryhwa [trzęsawisko] była, takaja jak idesz to szatajecca, dryżyć i jak sam waszou to nichto ne wyratuje. Takije mesta byli, ja znaju, szczo nichto ne iszou. Liudy znały szczo takije mesta, to tudy ne iszły. [...] Tam u liesach hrybiu, jahod było, poka hetoj osuszki [bagien] ne zrobyly, to do choliery było usioho [...] [Nadzieja Chodźko, ur. 1942, Wólka Wielka].

\section{Tradycje i zwyczaje}

Polesie niewątpliwie należy do tych obszarów Białorusi, gdzie tradycyjna kultura zachowała się w bardziej nienaruszonym stanie niż w innych regionach. Widać to nie tylko na przykładzie budownictwa (liczne drewniane domy z zachowanymi studziennymi żurawiami, zdobione drewnianymi okiennicami, krosna, kołowrotki czy niewody - sieci do łowienia ryb), ale i w zwyczajach czy obrzędach. Zmiany 
ostatnich dziesięcioleci wpływają jednak i na poleski krajobraz kultury. Trudno już spotkać osoby, które obecnie tkają na krosnach, wypiekają chleb czy przędą len, aby później utkać lniany ręcznik obrzędowy. Wielu naszych rozmówców wykonywało jednak większość tych czynności dawniej, co daje możliwość przekazywania sposobu ich wytwarzania czy kultywowania przez kolejne pokolenia. Poniżej przytaczamy kilka wybranych cytatów, ułożonych tematycznie:

a) uprawa i obróbka lnu

Lion wyraszczywaty, ja znaju szczo joho, po hodou nam piatnaccać buło, po szasnaccać tam de zaraz chata stoić, to tam takej buu ohrudok bol'szyj, kołotyly joho tymi pałkami, zaraz to maszyny, a [wtedy] pałkamy to obywaty, wozyly, dobre szczo teper hety maszyny, a tady to my urucznu [...] na polie sażaly joho, [potem] joho rwesz, u puczeczky stanowysz, da wysychaje win, da, kołoczwajesz, a potom [wykładają] joho na takuju czystyju płoszczad', nu ne znaju skol'ko tam jamu leżaty, źbirajuć ta wiażuć u puczkej i woziać do domu, a i konopliu tut u nas siejały. Zare to uże każuć szszo to narkotiki. Lion to ne moczyly, a konopliu to moczyty. Po chatach rozwozyly, taka kamniałka tut buła, suszyly na peczach, suszyły, potom perekruczwały, dawali takije trepaczki i trepaly urucznuju i zdawaty potom [...]. Tkaty, tkaty, take werstaci nazywałysia, buly, werstaci take, tut tkały, szyły i soroczky i rubaszky i płacja, szszo choczesz [Nadzieja Sidorczuk, ur. 1935, Wujwicze].

b) wypiekanie chleba

Chlib to i ja pekła, żytni, primerno takaja buła, nazywałasia diżka, specijal'no szczo $b$ chlib pekky, o, i ot tudy na nocz rosczynu takuju i postawysz u tioplom misty i ono prykisne, u rano zamiswajesz tak, a dalej pudejde ono tak i wymesisz i tak, [aż] pounaja ta diżka stane i do bliachy, wymażesz, take bliachy buty, he, ta tudy nakładajesz, piczka hariła, żar wyhonysz stul' i tudy chlib u pieczy. Muka i woda, bol'sze ne buto niczoho [Nadzieja Sidorczuk, ur. 1935, Wujwicze].

\section{c) swaty i zaręczyny}

Mołody znakomliacca, a potomki, bat'ko, maty ich biruć, krosnych biruć, tam dziadźka, ciotku, a tam uże dahawarwajucca. Bieruć chlieb, pieczuć, pirożki bieruć, jeszczo bieruć wodku, kwitku, a mołodaja nasypaje u wodku żyto, i uże dwie butył$k i$, u mołodej takaja butyłka i u mołodoho. I potom hetyje butyłki stojać, uże poslie hetoho jak pożeniacca, roditsja ditja, to tohda hetuju butyłku rospiwajuć [A zaruczyny?] Nu jak, lity wodku, pity, poczci jak swadźba. Szczo hotowyly [na wesele], szczo umity, i ryba i kotliety $i$ hałubcy i wo, sałaty, tam nie peredumajesz, mnoho bliud, i wodki mnoho [Nadzieja Chodźko, ur. 1942, Wólka Wielka].

d) wspominanie zmarłych

[A na mohiłki jeżu nieśli?] A nas ne beruć, ni wodki, ni zakusky, ni, eto nie pałożeno. Iduć tak postojać, cwiety pałożać i usio, może kanfietu pałożać, to na pasku jajca niesuć, na czetwerh hety, kladuć jajca, jeśli chto-to niedauno pomer, da hodu, a poslie hodu to ne kładuć, poslie hodu, to cwiety chto nese, to pieczennie położyć. No jeść po hetych siołach, to źbirajucca, beruć hetu, he, zakusku, uże swiatkujuć, na kładbiszcze, pomoliacca, cwiety położać [Nadzieja Chodźko, ur. 1942, Wólka Wielka]. 


\section{Praktyki znachorskie}

Podobnie jak w innych regionach Białorusi ${ }^{9}$, na polskim Podlasiu, łotewskiej Łatgalii, a także na białoruskim Polesiu można jeszcze zetknąć się na przykład z szeptuchami. Pomimo trwającej dziesiątki lat edukacji prowadzonej przez władze i stu lat walki zarówno Kościoła katolickiego, jak i Cerkwi prawosławnej z praktykami znachorskimi, miejscowa ludność, zarówno mieszkańcy wsi, jak i Pińska, do dzisiaj czasami korzystają z usług takich osób.

Praktyki znachorskie nie były rzadkie w dawnych czasach, o czym pisze Antoni Ferdynand Ossendowski: „W kureniach, po chatach, po zmurszałych młynach wodnych [...] żyją też dawne zahowory i zasiekania - czary i uroki, gdzie sędziwy kołtuniasty dziad lub w kabłąk ku ziemi przygarbiona starucha umie zamówić wszelką chorobę [...] lub też dopomóc w cierpieniu [...], czy aby krowy dawały dużo tłustego mleka" [Ossendowski 2010: 182, 183].

$\mathrm{W}$ trakcie przeprowadzania wywiadów z rozmówcami z początku widoczne było ukrywanie faktu, że osoby o takich umiejętnościach jeszcze mieszkają w danej miejscowości (toż my usie tut werujuszczyje, prawasłaunyje), jednak w dyskusji nasi informatorzy opowiadali już najróżniejsze historie związane ze znachorstwem:

[A szeptuchi byli?] A na bołotach, to ne, u nas, tut na bołotach, po dierieuniach, to tak, tam jest, sztob poszeptau [ktoś]. A chodyły liudi [A ad czaho lieczyła takaja szeptucha?] Ot udaru, ot perepuhu. A poslie wojny, to komunisty ne pryznawaty niczoho. A byu, o, w wojnu, major ci pułkounik, i z synom szczo-to słuczyłosia, $i$ nichto ne pomohau, ni doktory, $i$ [powiedzieli mu], szczo jeść u Dzikowiczach takej szeptuch. I zawioz swojho syna, [szeptuch] stawić joho tak i molitsja Bohu i potom diełaje na ścienie try razy chrest. I eto prochodzić. I ot pudwija, szto podduwajeć, toże [leczył]. Toże szczo-to szepczeć, howoryć, kakaja-to molitwa. Etot starik [szeptuch] on peredau po nasliedstwu ci doczki ci komu-tam. Win moh peredać komu chociu [swoje zdolności]. Takych szczo dobro dziełali, to mało, a takych szczo płocho, to bol'sze, tam nawredzić, naczarawać, takoho buło, buło, chto ne znaje [jak się bronić] to stradaje [Michał Dzikowicki, ur. 1926, Dzikowicze Wielkie].

Na uwagę zasługuje fakt, że praktyki te, sięgające czasów pogaństwa, wykorzystują elementy wiary prawosławnej. Mamy zatem doskonały przykład przenikania się czy też uzupełniania w sferze sacrum wątków chrześcijańskich

9 Powyższym zagadnieniem zajmują się białoruscy etnolodzy, m.in. Tatiana Wałodina. O dużym zainteresowaniu podobną tematykę świadczy chociażby fakt wydania w 2009 roku w Mińsku książki Замовы, w której Uładzimir Wasilewicz i Lija Saławej wyekscerpowali z materiałów badaczy terenowych liczne modlitwy i zaklęcia. Można wśród nich znaleźć teksty zaklęć mających chronić człowieka przed najróżniejszymi chorobami czy przed rzuceniem uroku. Również w Łatgalii praktyki takie są bardzo popularne (z badań własnych autora - M. J.). 
i pogańskich. Poniżej przytaczamy opis spotkania, w trakcie którego szeptucha zdejmowała urok $^{10}$.

Z niezbędnych rekwizytów potrzebnych szeptusze, zwanej przez miejscowych ciocią Galią ${ }^{11}$, na stoliku znajdowały się najzwyklejsze karty do gry, niewielka, trójskrzydłowa drewniana ikonka prawosławna przedstawiająca postać św. Mikołaja Cudotwórcy chroniącego wiernych od nieszczęścia i chorób. Na stole stał ponadto niewielki słoik po dżemie wypełniony ziarnami zbóż, w które wetknięta była prawosławna świeca. Po krótkiej rozmowie wstępnej (w gwarze poleskiej), kiedy szeptucha ocenia, czy na kogoś rzucono urok, czy też nie, zapala świecę i rozkłada karty na sześć kupek - to, co było, to, co jest, to, co będzie, w pracy, w miłości i w zdrowiu. Każda karta jest przypisana konkretnym osobom czy też wydarzeniom (np. król trefl lub pik oznacza żonatego mężczyznę o ciemnych włosach, karo i kier - o jasnych włosach, dama odpowiednio - zamężną ciemnowłosą lub jasnowłosą kobietę, a walet - nieżonatego mężczyznę). Następnie szeptucha opisuje dość dokładne, kto, kiedy i w jakich okolicznościach rzucił urok, jakiej mocy jest urok i czego dotyczy (np. żeby osoba poszkodowana nie miała szczęścia w pracy czy też nie ożeniła się i nie miała dzieci), a także, co człowieka w przyszłości czeka w miłości, pracy i zdrowiu. Po postawieniu diagnozy szeptucha nakazuje kupić i przynieść ze sobą na kolejną wizytę odpowiednie rekwizyty: bułkę, sól, wodę i trzy nowe lub wyprane koszule.

W trakcie drugiej wizyty następuje zdjęcie uroku. Szeptucha ponownie zapala świecę, która nie chce się palić, a następnie bułkę, koszule i wodę w butelce kładzie na stole, sól zaś (jako nieczystą, kumulującą zło) pozostawia na podłodze. Nad każdym z rekwizytów modli się po dziewięć razy. Jest to modlitwa do św. Mikołaja Cudotwórcy. Kolejnym etapem jest modlitwa (powtórzona również dziewięć razy) nad człowiekiem, na którego rzucono urok. Szeptucha trzyma rozłożoną dłoń nad głową poszkodowanego, a w drugiej ma ikonkę prawosławną. Widoczne rozpalenie się świecy jest znakiem, że urok został zdjęty.

Ostatnim etapem jest instrukcja, co osoba poszkodowana powinna robić. Przez kolejnych dziewięć dni należy trzy razy dziennie pić wodę i jeść bułkę. Ponadto każdą koszulę powinna nosić bez przerwy po trzy doby. W tym czasie nie wolno jej nikomu niczego pożyczać ani też darować długów. Szeptucha może również udzielić życiowych porad, na przykład: nie wolno nikomu niczego pożyczać po zapadnięciu zmroku lub w święta. Sól służy z kolei do ochrony: sypiąc ją w odpowiednim miejscu i czyniąc znak krzyża, można wypowiedzieć zaklęcie chroniące poszkodowanego przed konkretnym działaniem osób trzecich, które mają względem niego złe zamiary.

${ }^{10}$ Na podstawie obserwacji własnych; miałem możliwość uczestniczyć i przyglądać się całemu procesowi zdejmowania uroku - M. J.

${ }^{11}$ Imię zmienione. 
Język

Na badanym terytorium można stwierdzić obecność kilku funkcjonujących tam języków: rosyjskiego, białoruskiego i polskiego oraz gwar poleskich na podłożu ukraińskim. Znajomość poszczególnych kodów jest uzależniona przede wszystkim od wieku rozmówców, ale i od czasów, w jakich żyli i uczęszczali do szkoły.

Język rosyjski, a dokładniej miejscowa odmiana języka rosyjskiego, przechodząca momentami $\mathrm{w}$ trasiankę $\mathrm{w}$ mniejszych miasteczkach, dominuje przede wszystkim w Pińsku oraz wśród osób średniego i młodszego pokolenia, których edukacja przypadła na czasy sowieckie bądź niepodległej Białorusi. Język ten nie jest jednak pozbawiony lokalnej specyfiki: odczuwalne jest słabe akanie, zbliżające się do okania, wymowa dźwięcznego, frykatywnego $\gamma$ czy niezgłoskotwórczego $u$. Cechy lokalne widoczne są również w leksyce i morfologii.

Znajomość języka białoruskiego jest zazwyczaj bierna, wyniesiona ze szkoły. Zarówno w czasach sowieckich, jak i obecnie, w niepodległej Białorusi, dominują szkoły rosyjskojęzyczne, w języku białoruskim nauczane są standardowo dwa-trzy przedmioty. Trudno zatem spotkać, poza Pińskiem, kogokolwiek, kto w życiu codziennym posługiwałby się tym językiem.

Językiem polskim, zazwyczaj odgrywającym rolę języka sekundarnego, władają osoby najstarsze, które w okresie międzywojennym uczęszczały do polskiej szkoły. Znajomość polszczyzny pokazuje poniższa wypowiedź, mężczyzna przeszedł na język polski, kiedy dowiedział się, że jesteśmy z Polski:

To czego pan nie mówi po pol'sku, ja bende rozmawiat po pol'sku. Ja cztery kłasy konczył. Tam teraz [gdzie szkoła była] spalili Niemcy, tam teraz odyn chłop jest, co nam postroił dom, to tak, o, z wioski wyjci to, na prawo persza chata, wot tam o stoi, tam była szkoła, tam taki pliac ładny byt, a teper zarosło usio, bol'szewyky zrobyly wszystko tu, zapustyly. A ja po pol'sku i po niemiecku, i po ukrajinsku i pa biełarusku. I po swojmu [Michał Dzikowicki, ur. 1926, Dzikowicze Wielkie].

Jak widać z wypowiedzi powyżej, szybko następuje jednak przełączenie kodów i po chwili następuje powrót do języka prymarnego, czyli gwary poleskiej.

Mową najbardziej rozpowszechnioną wśród osób starszych mieszkających w wioskach jest niewątpliwie gwara poleska. Jak zwracają uwagę białoruscy językoznawcy, chociażby Aleksandr Krywicki czy Fiodor Klimczuk, białoruskie Polesie wyróżnia się ogromną różnorodnością grup gwarowych. Gwary zachodniopoleskie, zwane też brzesko-pińskimi (wschodnie nie są tematem niniejszych rozważań), dzielą się na północne i południowe, a zgodnie z podziałem zaproponowanym przez Klimczuka te dzielą się na: średniozahorodzkie, północnozahorodzkie, tarakanskie i południowozahorodzkie [Крывіцкі 2003: 210-214]. Badany rejon piński (a dokładnie - obszar położony na południe od rzeki Piny) w myśl przyjętego powyżej podziału należy do grupy gwar średniozahorodzkich. Do najważniejszych cech językowych, stale obecnych w wypowiedziach naszych rozmówców i rozpowszechnionych na badanym obszarze, można zaliczyć: ikawizm, okanie (brak 
akania), występowanie miękkich $\check{z}, \check{s}, \check{c}, r$ ', brak ciekania i dziekania (wymowa miękkich $t^{\prime}$ i $d^{\prime}$ ). Z cech morfologicznych są to np.: formy bezokolicznika czasowników: chodyty, robyty, pysaty, formy czasownika być w bezokoliczniku i formach czasu przeszłego: buty, buła, buli itd. Również w słownictwie możemy wyliczyć liczne leksemy charakterystyczne dla Polesia: werstać 'krosna', bat'ko, maty, seło, towar 'bydło' i wiele innych.

Wstępna analiza wykazała, że - w porównaniu do dialektów w innych regionach Białorusi - w rejonie pińskim możemy mówić o dobrym zachowaniu systemu gwary na wszystkich jej poziomach. Wpływ języka rosyjskiego, choć widoczny, nie jest zbyt silny i ogranicza się zazwyczaj do zleksykalizowanych słów i zwrotów (np. spasiba, zdrawstwujtie, pażałujista itp.) czy słów, które pojawiły się $\mathrm{w}$ ostatnich stu latach $\mathrm{w}$ związku z postępującą mechanizacją (np. terminologia kołchozowa i techniczna).

Na uwagę zasługuje bardzo duże zróżnicowanie gwarowe, nawet między sąsiadującymi ze sobą wsiami. Wystarczy oddalić się o kilka kilometrów czy przejść na drugi brzeg rzeki, by usłyszeć nieco inną mowę. Na fakt ten zwracali uwagę również nasi rozmówcy:

Znajete, mowa roznaja, kożnoje seło, my howorymo koń, tam kiń, a u Mistkowiczach kuń, wot takije i raźnicy. A u nas Pare jeść seło, to wony howorać usio na bukwu a, a u Żytnowiczach tak jak i u nas [Fieofan Siewieryn, ur. 1931, Mała Wólka]; U hetaj Bol'shej Wul'cy inaczej howorać, a tam [w Konczycach] i biłoruske-nibiłoruske i ukrajinskaje-neukrajinskaje. Tut „noż” howorać, tut jabłyko, a tam jebłyko, tut noża, tam nożje, tam każdaje słowo na bukwu je. Nichto ne znaje na jakoj mowie my howorym, ci biełaruskoj, ci wona ruskaja, ci ukrajinskaja. Szczytajemo Biłorusy, a po jakomu my howorym? Tam u Biłorusi, tam dal'sze [na północ] to zusim inacze howorać, tam na „dz”, tam „chadziła', „rabiła”, heto na Biłorusi tudy dal'sze, u nas chodyła, robyła [Nadzieja Chodźko, ur. 1942, Wielka Wólka].

Nasi rozmówcy nie zawsze potrafili jednym słowem określić czy też opisać swój język. Czasami nazywali go zmieszanym, innym razem dzieriewienskim, zazwyczaj podkreślali jednak, że różni się od innych „czystych” języków i łączy cechy białoruskie, ukraińskie i rosyjskie:

Ja ż ne znaju, my ź Biłorusi, a jak my howorym, ni po bełorusku ni po rusku, nie znaju po jakomu ja howoru, po derewensku. Usie Biłorusy dziekajuć, a my nie [...] [Nadzieja Sidorczuk, ur. 1935, Wujwicze];

A na uschodniaj Biełorusi, tam czysta pa biełarusku, a tut smieś, dialekt i ukrainskoj mowy i pol'skoj i naszej misnoj howorki [Marija Kazak, ur. 1937, Stajki].

Mieszkańcy wsi, zapytani, gdzie można usłyszeć czysty język białoruski, odpowiadali zazwyczaj, że na wschodzie Białorusi (Mohylewszczyzna, Homelszczyzna), a nawet bliżej - w rejonie stolińskim: 


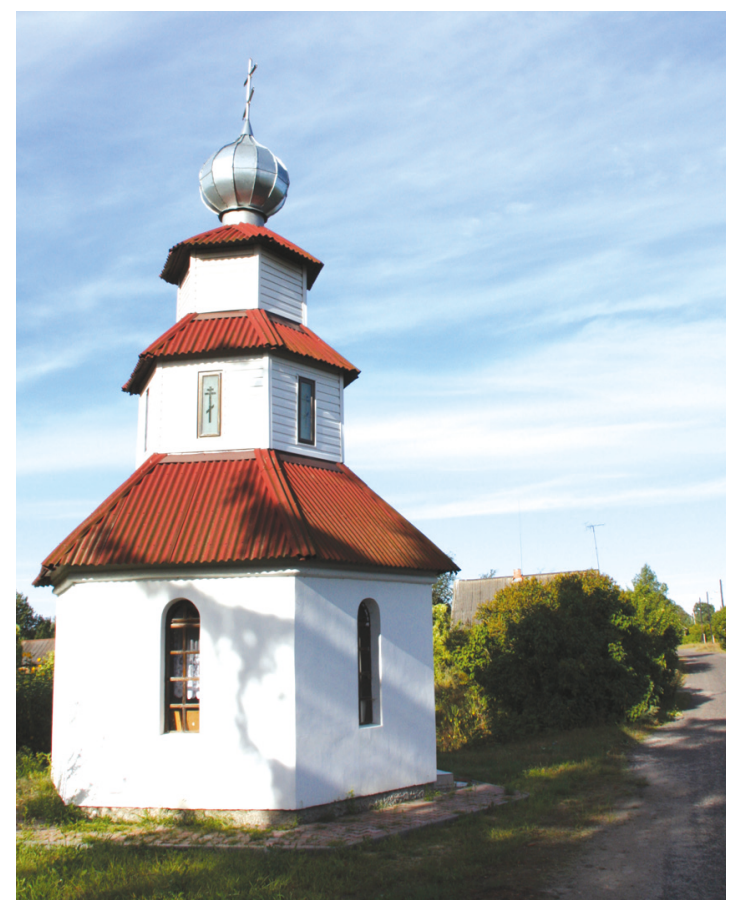

Fot. 1. Prawosławna

kapliczka w wiosce Stajki

(fot. M. Jankowiak)

Fot. 2. Żuraw studzienny w wiosce Dzikowiecze Wielkie (fot. M. Jankowiak)

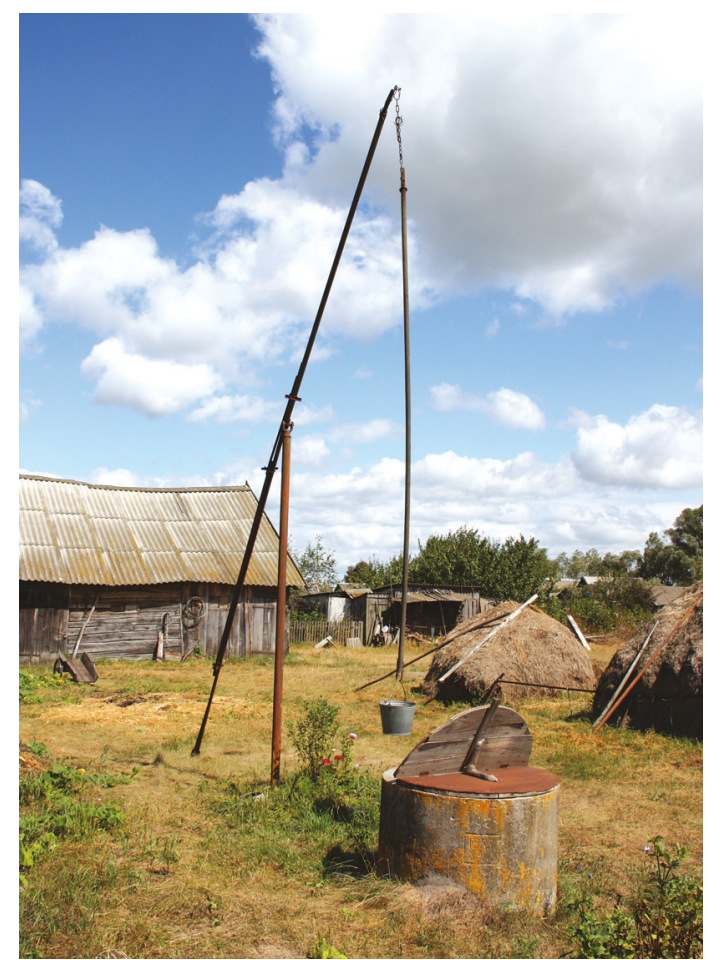




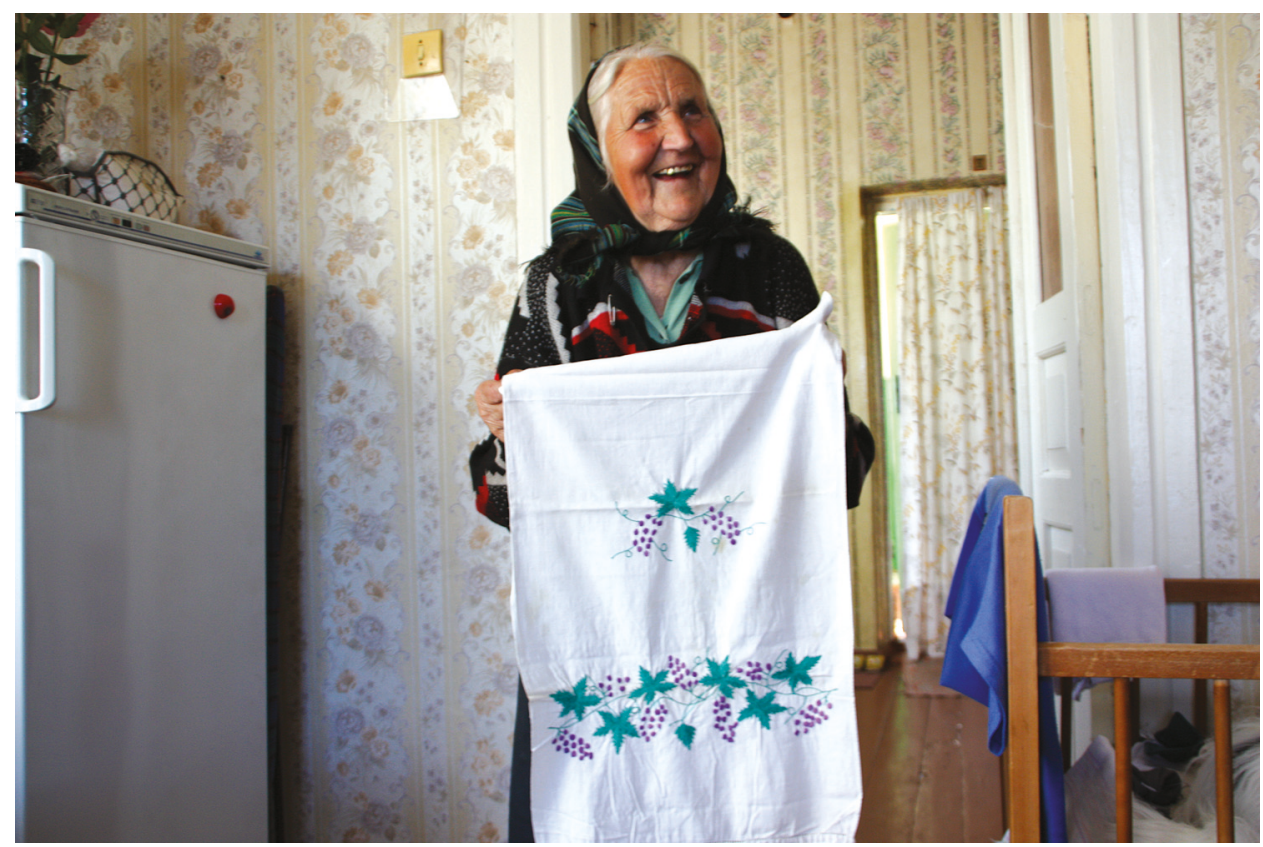

Fot. 3. Mieszkanka Miestkowicz pokazująca swoje rękodzieło (fot. Ł. Grajewski)

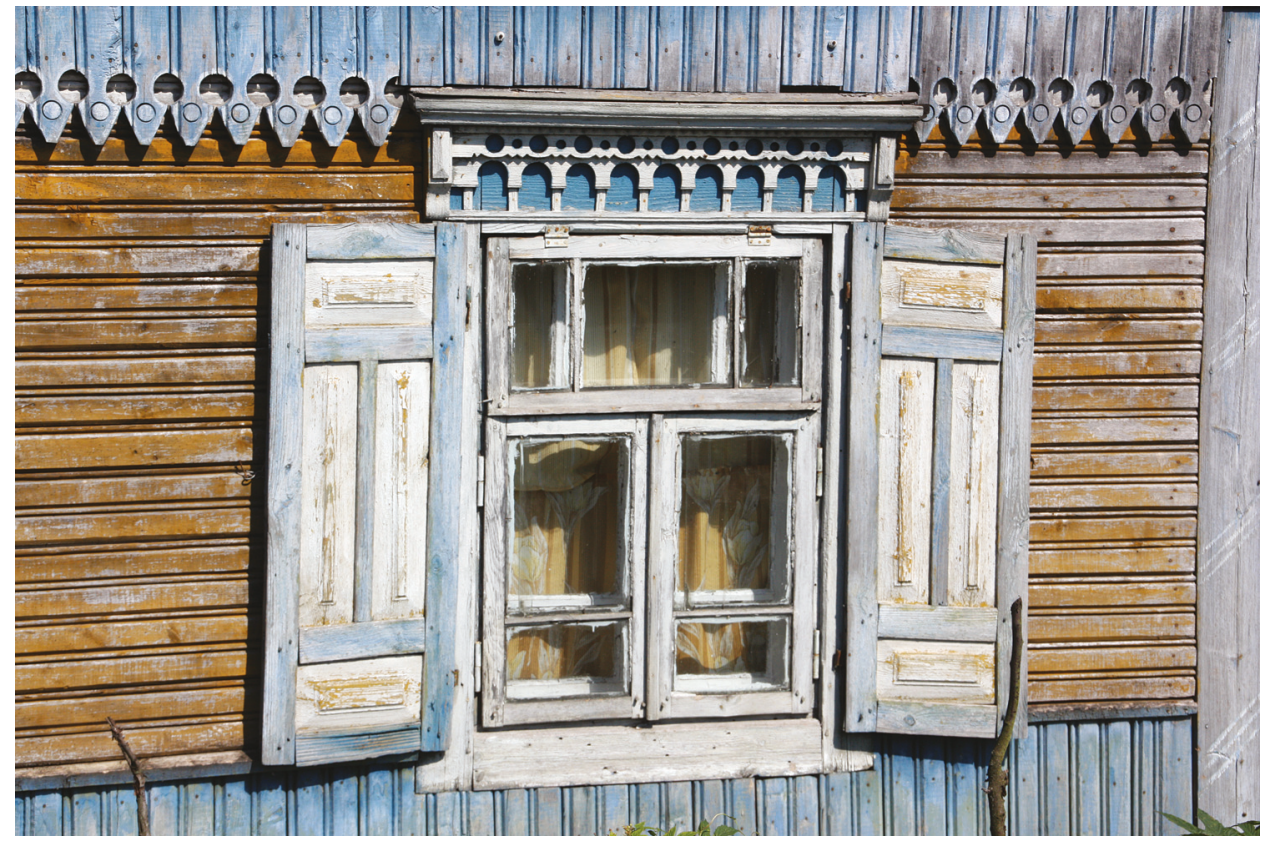

Fot. 4. Okiennice poleskiej chaty we wsi Wujwicze (fot. M. Jankowiak) 
[A czystaja biełaruskaja mowa?] A tut u Stolinie, Dawyd-horodku, na Dubiszcze tam, Mahiliou, Homiel' [Nadzieja Chodźko, ur. 1942, Wólka Wielka].

W przeważającej większości nasi rozmówcy odnosili się pozytywnie do swojej gwary i poza pierwszymi minutami rozmowy, kiedy starali się przejść na język rosyjski, abyśmy lepiej ich rozumieli, nie wstydzili się mówić gwarą poleską:

[A jakaja mowa wam padabajecca?] A hetaja, na jakoj my howorym, ruska-biełoruskaja, a ukrainskaja ne wel'mi, tam chaciakajut, szczo nie howorać, to [wszystko] na -oce. Usio ż tak my ponimajem, i tych i usich [Nadzieja Chodźko, ur. 1942, Wólka Wielka].

\section{Podsumowanie}

Obszar Polesia jest niewątpliwie jednym z najciekawszych regionów nie tylko na Białorusi, ale i w Europie. Złożyło się na to wiele czynników. Specyfika wynika $\mathrm{z}$ dwóch podstawowych faktów. Po pierwsze, jest to jeden z ciągle najbardziej archaicznych obszarów na kontynencie, gdzie zachowały się język i kultura tradycyjna, kultywująca wiele cech archaicznych. $Z$ drugiej strony zachodzą niezwykle szybkie zmiany społeczno-ekonomiczne, co daje badaczom reprezentującym różne dyscypliny możliwość zaobserwowania zmian o wiele szybciej i dokładniej niż na innych pograniczach.

Bogactwo Polesia wynika także ze specyficznego położenia. Leży bowiem na granicy etnosów (Polacy, Ukraińcy, Białorusini), języków (polski, białoruski, ukraiński, a od pewnego czasu także rosyjski) i religii (katolicyzm, grekokatolicyzm, prawosławie), co nie pozostało bez wpływu na ukształtowanie świadomości Poleszuków, ich kultury, tradycji, architektury i wreszcie gwar poleskich.

Jak zwraca uwagę Aleksandr Krywicki, Polesie mimo licznych badań dialektologicznych, które przeprowadzono w związku ze zbieraniem materiałów do dialektologicznego atlasu języka białoruskiego, a także badań prowadzonych w latach sześćdziesiątych i siedemdziesiątych przez Fiodora Klimczuka, ciągle nie jest wystarczająco dokładnie opisane przez językoznawców [Крывіцкі 2003: 201]. Niniejsze badania terenowe wpisują się w nurt badań dialektologicznych proponowanych przez tego filologa.

\section{LITERATURA}

Kabzińska I., 1999, Wśród kościelnych Polaków. Wyznaczniki tożsamości etnicznej (narodowej) Polaków na Białorusi, Warszawa.

Kłoskowska A., 1996, Kultury narodowe u korzeni, Warszawa.

Marczak M., 1935, Przewodnik po Polesiu, Brześć.

Obrębski J., 2005, Dzisiejsi ludzie Polesia i inne eseje, oprac. A. Engelking, Warszawa. 
Obrębski J., 2007, Studia socjolingwistyczne. Polesie, red. A. Engelking, Warszawa. Ossendowski A. F., 2010 (1934), Polesie, Poznań.

Rąkowski G., 2001, Czar Polesia, Pruszków.

Słownik geograficzny Królestwa Polskiego i innych krajów słowiańskich, 1884, red. F. Sulimierski, B. Chlebowski, W. Walewski, t. 8, Warszawa.

Szybieka Z., 2002, Historia Białorusi 1795-2000, Lublin.

Tarnacki J., 1936, Podział językowy Polesia na podstawie faktów leksykalnych, Warszawa.

Вярэніч В., 2009, Палескі архіў, рэд. Ф. Клімчук, Э. Смулкова, А. Энгелькінг, Мінск.

Замовы, 2009, укл. У. Васілевіч, Л. Салавей, Мінск.

Дыялектны слоўнік Брэстчыны, 1989, рэд. В. Малажава, Ф. Клімчук, Мінск.

Клімчук Ф., 1983, Гаворкі Заходняга Палесся: банетычны нарыс, Мінск.

Крывіцкі А., 2003, Дыялекталогія беларускай мовы, Мінск.

Лексіка гаворак беларускага прыпяцкага Палесся. Атлас. Слоўнік, 2008, рэд. Ф. Кл і м чук,

У. Кошчанка, Г. Вештарт, Мінск.

Народная культура Беларусі. Эниьклапедычны даведнік, 2002, рэд. В. Цітоў, Мінск. Памяць. Пінск, 1998, Мінск.

Чарн якевіч Ю., 2009, Атлас гаворак паўночна-ўсходняй Брэстчыны, Мінск.

\section{TRACING THE BELORUSSIAN POLESZUKS (A REPORT ON FIELD RESEARCH)}

\section{SUMMARY}

The present article is a report on field research conducted in summer 2010 in order to collect dialectological material. 13 localities were researched altogether: Pinsk and 11 villages of the Pinsk district and one village of the Stolin district. During the interviews the following topics were discussed: the language situation in the village, issues of national identity, visions of Polesia and Poleszuks, traditions and customs, issues of confession, attitude towards the process of draining bogs or image of Poland and Poles.

Belorussian linguists (e.g. A. Krywicki) take note of the fact that Polesia, despite frequent dialectological research, has not been described accurately enough by linguists. The rich material collected showed not only well-preserved dialects of Polesia of Ukrainian basis (slight influence mainly of the Russian language can be observed with people of the oldest generation) but also strong though disappearing spiritual and material culture of the inhabitants of Polesia. 


\section{ПО СЛЕДАМ БЕЛОРУССКИХ ПОЛЕШУКОВ (ОТЧЁТ ПО ИТОГАМ ПОЛЕВЫХ ИССЛЕДОВАНИЙ)}

\section{PEЗЮME}

Настоящая статья является рапортом полевых исследований, проведённых летом 2010 г. с целью сбора диалектологического материала. Исследование охватило 13 населённых пунктов - город Пинск, 11 деревень Пинского района и одну деревню Столинского района Брестской области Беларуси. В интервью затрагивались следующие темы: языковая ситуация в деревне, вопросы национального самосознания, образы Полесья и полешуков, традиции и обычаи, вопросы вероисповедания, отношение к процессу мелиорации, а также образ Польши и поляков.

Белорусские филологи (напр. А. Кривицкий) обращают внимание на то, что несмотря на многочисленные диалектологические исследования, Полесье остаётся территорией, которая всё ещё недостаточно подробно описана языковедами. Собранный обширный материал показал не только хорошо сохранившиеся полесские диалекты с украинской основой (среди респондентов старшего поколения видны незначительные влияния в основном русского языка), но и до сих пор сильную, хотя и угасающую духовную и материальную культуру полешуков.

Słowa kluczowe: Polesie, Poleszucy, gwary poleskie, dialektologia białoruska.

Key words: Polesia, Poleszuks, dialects of Polesia, Belorussian dialectology.

Ключевые слова: Полесье, полешуки, полесские диалекты, белорусская диалектология. 